\title{
Importance of age in outcome of oesophagogastroduodenoscopy in open access endoscopy: a profile of patients in Sub-Himalayan region of North India
}

\author{
B. Sharma, V. Chauhan, N. Sharma, J. Mokta, S.Thakur, S.S. Kaushal
}

\begin{abstract}
Abstrak
Oesofago-Gastro-Duodenoscopy (OGD) dilakukan pada pasien yang diterima melalui sistem "open acces" dan sistem biasa. Keluhan dapat berbeda pada pasien yang berumur < 45 tahun atau yang berumur > 45 tahun. Diagnosis rujukan, umur, gender dan faktor lingkungan dapat menimbulkan implikasi penting. Studi ini ditujukan untuk mempelajari profil pasien yang datang untuk OGD berdasarkan usia (< 45 tahun atau > 45 tahun) antara Januari 2004 - Desember 2004 yang dirujuk berdasarkan "open acces system" di wilayah sub-Himalaya, India Utara. Studi ini dilakukan di Indira Gandhi Medical College. Pasien dibagi dua kelompok: Kelompok I usia < 45 tahun dan kelompok II usia $\geq 45$ tahun. Dari 1186 pasien, 451 (38\%) adalah perempuan, 735 (62\%) adalah laki-laki. Enam ratus enambelas pasien (52\%) berusia < 45 tahun dan 570 (48\%) berusia > 45 tahun. Dari kelompok I, 431 (70\%) menunjukkan gambaran endoskopi yang normal dan 185 (30\%) menunjukkan kelainan. Pada kelompok II 302 (53\%) menunjukkan gambaran endoskopi yang normal, dan 268 (47\%) memperlihatkan kelainan pada endoskopi. Ulkus gaster dan masa lebih sering terlihat pada kelompok > 45 tahun. "Gastro-esophageal reflex disease” (GERD) lebih sering pada usia muda. Gejala subjektif sama pada kedua kelompok. Disimpulkan bahwa untuk gejala yang sama, kelainan OGD lebih sering pada kelompok usia > 45 tahun. Hasil positif meningkat dari 30\% menjadi $47 \%$ antara usia $<45$ dan $>45$ tahun. Disimpulkan bahwa semua pasien usia $>45$ tahun perlu dirujuk untuk endoskopi pada kali pertama kelainan gastrointestinal atau adanya alarm simtom. (Med J Indones 2006; 15:90-3)
\end{abstract}

\begin{abstract}
The Oesophago-Gastro-Duodenoscopy $(O G D)$ is done in patients received by either open access system or the conventional system. The presenting complaints and OGD findings may differ among patients with age $<45$ yrs and those who are more than 45 yrs old. The referral diagnosis, age, sex, and environmental factors have important implications on the chances of finding and objective abnormality on endoscopy in a patient. This study was aimed to evaluate to evaluate the profile of 1186 patients divided into younger (<45 yrs) and older age (45 or > 45 yrs) groups presenting for oesophago gastroduodenoscopy through open access referral system in sub-Himalayan region of North India. This is a retrospective study carried out on patients who underwent the OGD from Jan, 2004Dec, 2004. The study was conducted in Indira Gandhi Medical College situated at a moderate altitude in North India. All patients presenting in Medical College during the study period for OGD were taken into study. The patients were divided into two groups based on age; less than 45 yrs and 45 yrs or more than 45 yrs. Their presenting complaint, age, sex, and OGD findings were recorded. The profile was compared between the two groups. A total of 1186 patients underwent OGD; the females were $451(38 \%)$ and males were 735(62\%); 616(52\%) were < 45 yrs old and 570(48\%) of the patients were 45 yrs or older. In the group I 431(70\%) had a normal endoscopy and 185(30\%) showed abnormal endoscopic findings. In group II 302(53\%) had a normal endoscopy, and $268(47 \%)$ had abnormal findings on endoscopy. Gastric ulcers, mass lesion/new growth were more common in elderly group, Gastroesophageal reflux disease (GERD) was more common in younger group. The presenting complaints were similar in both groups. It is concluded that for the same presenting diagnosis the yield of OGD was more in patients > 45 yrs old. The positivity rate increased from $30 \%$ in $<45$ yrs to $47 \%$ in the elderly cohort. So, all people $>45$ yrs should go for endoscopy at the first hint of upper GI pathology, or appearance of alarm symptoms. (Med J Indones 2006; 15:90-3)
\end{abstract}

Keywords: endoscopy, open access, dyspepsia, dysphagia

The open access system allows all practitioners to refer the patients for OGD with a short waiting list of

Department of Medicine, Indira Gandhi Medical College, Shimla-171001(H.P.)
1-6 days. This system does not require a prior consultation of a gastroenterologist. This system is adopted now in most institutions to avoid delay in the diagnosis of patients. There are different guidelines stating endoscopy as an initial evaluation for dyspepsia or dysphagia especially if age is more than 40 or 45 years. ${ }^{1,2}$ While some advocate restricted use of 
endoscopy and consider it unnecessary in dyspepsia without alarm symptoms below 45 years of age. ${ }^{3}$ Open-access gastroscopy in primary health-care offices significantly reduces NSAID-related ulcer mortality and may also reduce overall ulcer-related hospitalizations. ${ }^{4}$ The aim of the study was to evaluate the difference in the presenting complaints in the two age groups and to see the difference in outcome of the endoscopy in both groups.

\section{METHODS}

This retrospective study was conducted in all patients presenting in Indira Gandhi Medical college endoscopy unit in one year through open access system for OGD. Their referral diagnosis, chief complaints, age, sex, address, and OGD findings were recorded. Dyspepsia was defined as persistent or recurrent abdominal pain or abdominal discomfort, centred in the upper abdomen, with duration of at least 3 months. Discomfort was characterized by early satiety, postprandial fullness, nausea, retching, upper abdominal bloating, anorexia, heartburn and/or regurgitation. A circumscribed break in the mucosa with a considerable depth $(>5 \mathrm{~mm})$, covered with exudate, present in the pre-pyloric, pyloric or duodenal bulb region, was classified as duodenal ulcer (DU). Gastric ulcer (GU) was diagnosed when the above-described mucosal defect was located at the angulus or above. Gastric or duodenal ulcer was diagnosed in the case of either an active ulcer or a deformity of the duodenal bulb. GERD was diagnosed in the case of apparent (haemorrhagic, erosive or ulcerative) mucosal alterations. In the case of specific findings (gastric ulcer, polyps, erosions, cancer), biopsies were taken for histological assessment. The findings of OGD were divided into gastric ulcer (GU), duodenal ulcer (DU), varices, erosions, mass/new growth, GERD, abnormal looking mucosa etc. The patients were divided based on age into two groups. Group I age less than 45 and Group II 45 yrs or older. The findings were recorded and analyzed and comparison was made between the two groups especially the presenting diagnosis, age, and sex distribution and OGD findings.

\section{RESULTS}

Total of 1186 patients underwent OGD; the females were $451(38 \%)$ and males were $735(72 \%)$. The mean age was 44 yrs with age range of (12-85 yrs). $213(18 \%)$ were more than $60 \mathrm{yrs}$ old, $616(52 \%)$ were in Group I. Overall, 735 (62\%) had normal OGD with mean age of $42 \mathrm{yrs}$. When analyzed separately those who were in Group I (total no. 616) had more chances of a normal OGD i.e. $431(70 \%)$ normal endoscopy as compared to the Group II (total no. 570) with OGD normal in only $302(53 \%)$. The main difference in both groups was the incidence of mass lesions/ new growth on OGD (Table 1). The Group II mass lesion constituted 34/267 (13\%) of the abnormal findings (total 267) as compared to Group I in which $10 / 185(5 \%)$ of the abnormal OGDs (total 185) showed mass lesion. The incidence of gastric ulcer was more 56/267(21\%) of abnormal findings (total 267 ) in Group II as compared to $22 / 185$ (12\%) in Group I.

The presenting diagnosis in two groups was similar and comparable and both groups (Table 2) had similar profile of presenting diagnosis except for increased incidence of dysphagia in Group II $33(6 \%)$ as compared to 10 (2\%) in Group I. After analysis we found that despite similar presenting complaints in both groups, the patients in Group II are more likely to have abnormal endoscopy results.

Table 1. Breakup of abnormal findings on OGD in the two groups of patients

\begin{tabular}{lccccccc}
\hline Age & DU & GU & GERD & VARICES & $\begin{array}{c}\text { MASS/NEW } \\
\text { GROWTH }\end{array}$ & $\begin{array}{c}\text { OTHERS } \\
\text { TBNORAL } \\
\text { OGDs }\end{array}$ \\
\hline$<45$ yrs & 76 & 21 & 27 & 25 & 10 & 26 & 185 \\
$($ Group I) & $(41 \%)$ & $(11 \%)$ & $(15 \%)$ & $(14 \%)$ & $(5 \%)$ & $(14 \%)$ & 40 \\
$>45$ yrs & 83 & 56 & 19 & 34 & 36 & $(13 \%)$ & $(15 \%)$ \\
(Group II) & $(31 \%)$ & $(21 \%)$ & $(7 \%)$ & $(13 \%)$ & & 268 \\
\hline
\end{tabular}


Table 2. Breakup of the presenting complaints in groups-I and group-II

\begin{tabular}{lccccccc}
\hline Age & ALD & ANEMIA & DYSPEPSIA & DYSPHAGIA & UGI BLEED & OTHERS & TOTAL \\
\hline Group I (<45 yrs) & $16(2 \%)$ & $6(1 \%)$ & $477(77 \%)$ & $10(2 \%)$ & $73(12 \%)$ & $34(6 \%)$ & 616 \\
Group II (> 45 yrs) & $20(3 \%)$ & $14(2 \%)$ & $394(69 \%)$ & $33(6 \%)$ & $72(13 \%)$ & $37(7 \%)$ & 570 \\
\hline
\end{tabular}

All the complaints were seen more commonly in males except dysphagia which was seen more frequently in females. In patients presenting with dysphagia, abnormality at OGD were found in 30(65\%) patients, and a major pathology was found in 20(42\%) and female gender with this finding was more common in our study $28(60 \%)$. All the findings on OGD were commoner in males except the mass/new growth which was seen more commonly in females.

\section{DISCUSSION}

Less than 45 years is an age at which, according to different guidelines, referrals are not indicated because organic diseases are rare ${ }^{3}$. Structured and supported recommendations for both undiagnosed and endoscopically investigated dyspepsia have been proposed to avoid unnecessary endoscopies. Some favour increased investigation to detect Barrett's oesophagus and carcinoma. However, there is inconclusive evidence that patients without alarm signs will benefit subsequently from endoscopy, while investigation involves a small but real risk of harm. ${ }^{3}$ But our study clearly shows that approximately $30 \%$ patients had abnormal endoscopy findings in $<45$ yrs. And most common (55\%) were PU, also $6 \%$ of the total abnormalities detected were mass lesion/new growth which is an ominous finding.

OGD is an effective and an appropriate tool for the initial evaluation of patients presenting with dysphagia. Early OGD should be considered, particularly, in male patients aged more than 40 years old who concomitantly report heartburn, odynophagia, or weight loss. ${ }^{2}$ In one study abnormal findings at OGD were found in $70 \%$ of the patients, and a major pathology was seen in $54 \%$. Male gender, heartburn, and odynophagia predicted the presence of major pathology. ${ }^{1}$ Our study was in contrast to the findings of this study as female gender was more common in our study $(60 \%)$. Abnormal findings at OGD were found in $65 \%$ patients, and a major pathology in $42 \%$.
The most common presenting complaint was dyspepsia as is seen in all age groups. In the Group II, the positivity rate of dyspepsia is higher as compared to the Group I. The most common finding in patients with dyspepsia was peptic ulcer disease followed by mass or growth visible on OGD requiring biopsy. The second most common complaint bringing these patients for OGD was Upper gastrointestinal (UGI) bleed which had a high positivity rate. Most cases were due to peptic ulcer disease in our group of patients. Another group was of patients presenting with dysphagia, which is the most ominous of the presenting complaints with a high positivity yield in our study. Other findings were esophageal varices, gastric outlet obstruction and reflux esophagitis, which were not very common.

The referral diagnosis was comparable in both groups except for slight higher percentage of dysphagia in Group II. But the positivity rate of OGD was $47 \%$ in Group II as compared to $30 \%$ in the Group I despite similar presenting complaints. GERD was more common in Group I. Gastric ulcers and mass lesions/new growth was more common in Group II with almost double percentage. The increased incidence of peptic ulcer disease in the elderly holds true in our cohort also and our findings are consistent with the other studies in elderly. Varices and mass/new growth lesions were the other common findings which were found in this cohort whether they present with dyspepsia, UGI bleed, or dysphagia.

There is a need to emphasize the early OGD in the Group II, especially in patients with alarm symptoms, persistent dyspepsia despite treatment, UGI bleed, and dysphagia. The yield of OGD is high, and timely treatment can reduce the morbidity in the population with UGI complaints. At the same time the need for endoscopy in younger patients cannot be ruled out, because we will be missing many early cases of mass lesions/new growths. 


\section{REFERENCES}

1. Varadarajulu S, Eloubeidi MA, Patel RS et al. The yield and the predictors of esophageal pathology when upper endoscopy is used for the initial evaluation of dysphagia. Gastrointest Endosc. 2005 Jun;61(7):804-8.

2. Liou JM, Lin JT, Wang HP et al. The optimal age threshold for screening upper endoscopy for uninvestigated dyspepsia in Taiwan, an area with a higher prevalence of gastric cancer in young adults. Gastrointest Endosc. 2005 Jun;61(7):819-25.
3. Mason JM, Delaney B, Moayyedi $\mathrm{P}$ et al. Managing dyspepsia without alarm signs in primary care: new national guidance for England and Wales. Aliment Pharmacol Ther. 2005 May 1;21(9):1135-43.

4. Voutilainen M, Kunnamo I. Open-access gastroscopy in primary health-care offices to prevent peptic ulcer-related hospitalization and mortality. Scand J Gastroenterol. 2004 Dec; 39(12):1289-92. 